\title{
Effect of the cooling rates on heat-affected zone of UNS S32304 duplex stainless steel welded by pulsed GTAW process
}

\author{
${ }^{1}$ Betini, E.G.; ${ }^{1}$ Gomes, M. P.; ${ }^{1}$ Reis, L. A.; ${ }^{1}$ Mucsi, C. S.; ${ }^{1}$ Alencar, M. C.; ${ }^{2}$ Orlando,
} M. T. D.; ${ }^{2}$ Luz, T. S.; ${ }^{3}$ Avettand-Fènoël, M-N.; ${ }^{1}$ Rossi, J. L.

1 Instituto de Pesquisas Energéticas e Nucleares - IPEN, Brazil

2 Universidade Federal do Espírito Santo - UFES, Brazil

3 Universidade de Lille 1 - ULille1, France

*e-mail: evandrobetini@gmail.com

\begin{abstract}
Two thin plates of UNS 32304 of duplex stainless steel were joined by pulsed gas tungsten arc welding (GTAW) using a mixture $98 \%$ of argon plus $2 \%$ of nitrogen as shielding gas or pure argon as purging gas at the bottom of the plate without filler metal. The temperature profile close and away from the weld pool was measured using $\mathrm{K}$ type (Ni-Cr) thermocouples, connected to a digital data acquisition system. The thermal cycles was recorded in the heat-affected zone (HAZ) at a distance in between 1 and $3 \mathrm{~mm}$ from the joint line. The cooling rate and holding time were studied with respect to the used purging gas. Experimental thermal profiles are in good agreement with literature values. The joints welded without any purging gas revealed high peak temperature and cooling rates. The present investigation showed that temperature peaks are comprised in the phase transformation temperature ranges for the welded duplex stainless steel.
\end{abstract}

Keywords: GTAW, duplex stainless steel, cooling rate, thermal profiles.

\begin{abstract}
Resumo
Duas placas de aço inoxidável duplex UNS S32304 foram soldadas através do processo GTAW pulsado utilizando $98 \%$ de argônio mais $2 \%$ de nitrogênio como gás de proteção e argônio puro como gás de purga sem metal de adição. Os perfis de temperaturas próximos e ao longo da poça de fusão foram medidos usando termopares tipo $\mathrm{K}$ ( $\mathrm{Ni}$ - $\mathrm{Cr}$ ), conectados em um sistema de aquisição de dados. Os perfis térmicos foram alcançados na zona afetadas pelo calor em regiões entre 1 e $3 \mathrm{~mm}$ de distância do cordão de solda. Além disso, as taxas de resfriamento e o tempo de permanência foram observados com respeito ao gás de purga utilizado. As medidas experimentais de ciclo térmico estão de acordo com os valores da literatura. As soldas realizadas sem qualquer tipo de gás de proteção revelaram maiores picos de temperatura e maiores taxas de resfriamento. $O$ estudo da distribuição de temperatura resultou em picos de temperatura no intervalo da transformação de fases para as placas soldadas de aço inoxidável duplex.
\end{abstract}

Palavras chaves: soldagem GTAW, aço inoxidável duplex, taxa de resfriamento, perfil térmico.

\section{Introduction}

Duplex stainless steels (DSS's) have basically ferriticaustenitic microstructure that combines excellent properties when high corrosion resistance and superior mechanical properties are required. The last two decades have seen a trend towards a growing application of duplex stainless steels (DSS). Allied to a competitive cost the DSS also present satisfactory weldability [1].

The GTAW processes are generally preferred because they produce very high quality welds [2]. In many cases distortion is the major problem in welding of thin sections. However, the distortion is controlled in pulsed and magnetic arc oscillation GTAW process. Metallurgical advantages of pulsed and magnetic arc oscillation welds that are frequently reported in the literature include grain refinement in the solidified zone, reduced width of heat-affected zone (HAZ), less distortion, control of segregation, reduced hot cracking sensitivity and reduced residual stresses [3]. Weld root quality of stainless steel pipe and tubes can be ensured by removing the air from the fusion zone using an inert purging gas. Unsatisfactory purging results in formation of ferrochromium layers of colored oxide films commonly referred to as "heat tints." Pure Ar is the most commonly used purging gas in GTA welding of several grades of steels [4]. In addition, at least $2 \%$ nitrogen would be recommended in pure argon mixture for shielding gas for optimizing the phase balance and impact toughness do DSS [5]. Taking all aspects into account, $\mathrm{Ar}+2 \% \mathrm{~N}_{2}$ is the preferred shielding gas for welding duplex and super duplex with the GTAW process $[5,6]$. 
The fusion welding process modifies the ferriteaustenite phase balance in duplex stainless steels and promotes the intermediate-phases' precipitation in the welded joints [6,7]. In $\mathrm{HAZ}$, during the thermal cycle, the alloy is heated to a very high temperature above 1350 ${ }^{\circ} \mathrm{C}$ for a short time, held for a few seconds and subsequently cooled to room temperature [7]. In the heating and holding period, most of the $\mathrm{Y}$-austenite islands in the duplex structure dissolve into the $\delta$-ferrite matrix, and $\delta$-ferrite there is a coarsening of grains. Subsequently, during the cooling stage in the temperature range between 1350 and $800^{\circ} \mathrm{C}$, austenite re-precipitates around ferrite grain boundaries. In fact, higher heat input and thinner plates result in a slower cooling rate [6]. In this way, adjustment of a low cooling rate allows adequate austenite formation, but not too low in order to avoid precipitation of intermetallic phases $[6,8]$. Finally, the final microstructure depends on the parameters of welding cycles such as holding time, peak temperature, and cooling rate $[6,7,8]$. So, the aim of this experimental work is to optimized welding parameters in order to ensure the soundness better quality of the fabricated parts [9].

\section{Experimental procedure}

The dimensions of the DSS plate are $72 \times 72 \times 1.8$ $\mathrm{mm}^{3}$. Table 1 shows the chemical composition of UNS S32304 duplex stainless steel certified by the commercial supplier Aperam Inox América do Sul S/A. The DSS plates were welded at the Welding Laboratory of the Federal University of Espírito Santo (LabSolda/DEM/UFES). The pulsed current and direct polarity were used with automatic drive systems. The samples were fixed in order to reproduce the conventional welding process, as shown in Fig. 1. A batch of samples was welded with commercial argon as purging gas and another one with a mixture of argon

Table 1: Chemical composition (ppm and mass \%) of UNS S32304 steel.

\begin{tabular}{lc}
\hline Element & Mass \% \\
\hline $\mathrm{C}$ & 0.016 \\
\hline $\mathrm{Mn}$ & 1.40 \\
\hline $\mathrm{Si}$ & 0.250 \\
\hline $\mathrm{P}$ & 0.023 \\
\hline $\mathrm{S}$ & 0.001 \\
\hline $\mathrm{Cr}$ & 22.20 \\
\hline $\mathrm{Ni}$ & 3.52 \\
\hline $\mathrm{Mo}$ & 0.255 \\
\hline $\mathrm{N}$ ppm & 1030 \\
\hline $\mathrm{Ti}$ & 0.0041 \\
\hline $\mathrm{Cu}$ & 0.417 \\
\hline $\mathrm{Co}$ & 0.090 \\
\hline $\mathrm{Fe}$ & bal \\
\hline
\end{tabular}

and $2 \%$ of nitrogen as shielding gas (see Table 2 ). The gas flow rates were 10 L. $\mathrm{min}^{-1}$ for shielding gas and 6 L. $\min ^{-1}$ for purging gas.
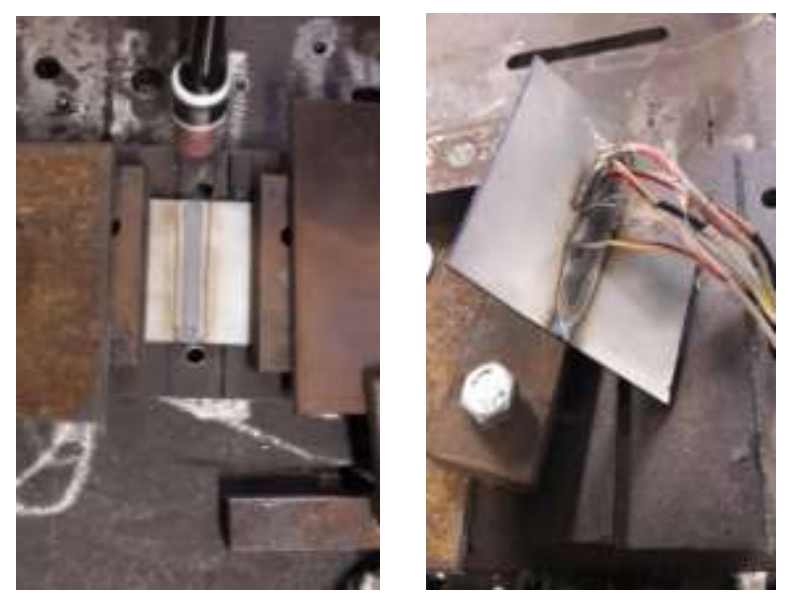

Figure 1: Welding arrangement for the duplex stainless steel UNS S32304 thin plates.

Table 2: Welding condition for the measurement of cooling rates.

\begin{tabular}{lc}
\hline Samples & Welding condition \\
\hline$\# 1 \mathrm{~N}$ & $\begin{array}{r}98 \% \mathrm{Ar}+2 \% \mathrm{~N}_{2} \text { as shielding gas } \\
\text { without purging gas. }\end{array}$ \\
\hline \#2NP & $\begin{array}{l}98 \% \mathrm{Ar}+2 \% \mathrm{~N}_{2} \text { shielding gas } \\
\text { with } 99,9 \% \mathrm{Ar} \text { as purging gas }\end{array}$ \\
\hline
\end{tabular}

The electrical current and voltage values were measured at each welding step. The AWS Class EWTh-2 electrode which remained negative was located at $2 \mathrm{~mm}$ with a $90^{\circ}$ angle from the plate, according to direct polarity process. The welding and thermal cycle parameters are indicated in Table 3.

Regarding the parameters such as voltage (U), pulsed and background current (Ip, Ib), pulsed and background time (tp, tb), the welding speed ( $v$ ) along with $60 \%$ arc efficiency for the pulsed GTA welding, it was possible to calculate the welding heat input $(\mathrm{H})$ per $\mathrm{mm}$ using Eq. 1 [10]. The welding heat input shown in Table 2 was determined using the average voltage, current and the welding speed.

$\mathrm{H}=60 \cdot U \cdot(I p \cdot t p+I b \cdot t b) /((t p+t b) \cdot v)$

The temperature was measured and recorded using thermocouples K-type attached to a data acquisition system. Four thermocouples were positioned and fixed to the sample plate's surface ( Fig. 2) using high voltage capacitive discharge generator at different distances, along transversal and longitudinal lines of the weld bead. The thermocouples were located at 1.0, 1.5, 1.8 and $3.0 \mathrm{~mm}$ from the joint line. 
Table 3: Welding parameter used for the pulsed GTAW process.

\begin{tabular}{lc}
\hline Shielding gas & $\mathrm{Ar}+2 \% \mathrm{~N}_{2}\left(10 \mathrm{~L}^{\mathrm{min}} \mathrm{m}^{-1}\right)$ \\
\hline Purging gas flow rate & Pure argon $\left(6 \mathrm{~L}_{\mathrm{min}}{ }^{-1}\right)$ \\
\hline Voltage & $11 \mathrm{~V}$ \\
\hline Pulse current $\left(\mathrm{I}_{\mathrm{p}}\right)$ & $140 \mathrm{~A}$ \\
\hline Background current $\left(\mathrm{I}_{\mathrm{b}}\right)$ & $70 \mathrm{~A}$ \\
\hline Pulse time $\left(\mathrm{t}_{\mathrm{p}}\right)$ & $0.9 \mathrm{~s}$ \\
\hline Background time $\left(\mathrm{t}_{\mathrm{b}}\right)$ & $0.9 \mathrm{~s}$ \\
\hline Welding speed & $35 \mathrm{~cm} \cdot \mathrm{min}^{-1}$ \\
\hline Arc efficiency & $60 \%$ \\
\hline Heat Input & $0.17 \mathrm{~kJ} \cdot \mathrm{mm}^{-1}$ \\
\hline
\end{tabular}

The signals from the thermocouples were acquired by 8-channel universal data acquisition system (DAQ) amplifier using MX board - PT1000 for room temperature automatic conditioning. The measured total error limit at $300 \mathrm{~K}$ ambient temperature is $\pm 1 \mathrm{~K}$ and the temperature drift ( $\mathrm{K}$ type) was used $\mathrm{K} / 10 \mathrm{~K}$ ratio where the uncertainty was $\leq \pm 0.5$.

\section{Results and discussion}

\subsection{Thermal cycle}

Figure 2 shows the welded plates after the pulsed GTAW welding process with thermocouples position. Note that for sample without any purging gas, in Fig. 2 (a), has a larger welding zone width (around $12 \mathrm{~mm}$ ) than the sample welded with pure Ar as purging gas (10 $\mathrm{mm}$ ), in Fig. 2 (b). Taban et. al. [4] also observed the differences between the no-purged and purged welds in surface of $304 \mathrm{H}$ pipes. The purged welds were much cleaner with brighter colors compared to the no-purge weld.

Temperature distributions were plotted for both specimens in Fig. 3. First, for Fig. 3 (a) the thermocouples TK1 and TK2 $(1.5 \mathrm{~mm}$ and $1.0 \mathrm{~mm}$ away from the joint line) were placed closer to the weld bead where the temperatures were close to $736{ }^{\circ} \mathrm{C}$ and $1080{ }^{\circ} \mathrm{C}$, respectively. The TK3 and TK4 thermocouple presents peak temperature in symmetric regions close to the HAZ and base metal interface.
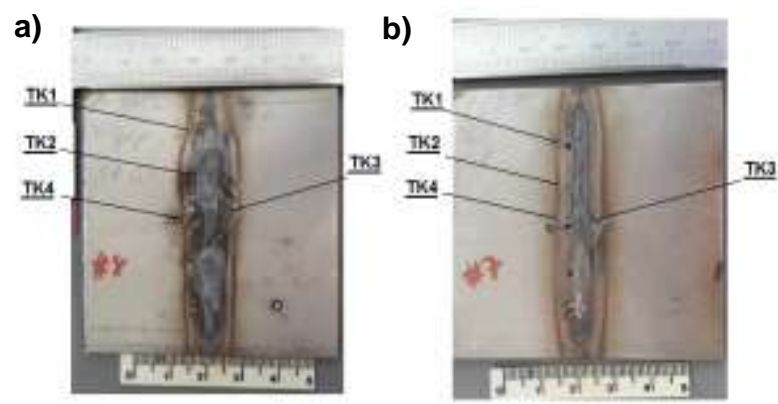

Figure 2: The welded plates with thermocouples location. a) indicates the welded plate $\# 1 \mathrm{~N}$ without any purging gas and $\mathrm{b}$ ) the plate using pure Ar as purging gas.
Fig. 3 (b) presents the temperature distribution for $\mathrm{Ar}+2 \% \mathrm{~N}_{2}$ with pure argon as purging gas sample. The higher peak of temperature close to $950{ }^{\circ} \mathrm{C}$ was observed in TK3 thermocouple $(1.0 \mathrm{~mm}$ from the welding line). This value is around $130{ }^{\circ} \mathrm{C}$ less than for sample \#1N without any purging gas in the same welding region. This indicates that the influence of the purging gas used for sample \#2NP. For TK1 and TK2 thermocouples, values above $700{ }^{\circ} \mathrm{C}$ were measured at the interface between solidified zone and HAZ. According to Muthupandi et. al and Lin et. al, the Ar-N2 mixture has a higher ionization potential, increasing the welding energy and the peak temperature. The overheating in the weld joint causes changes on the cooling rates and consequently effects on the microstructural evolution $[12,13]$.

a)

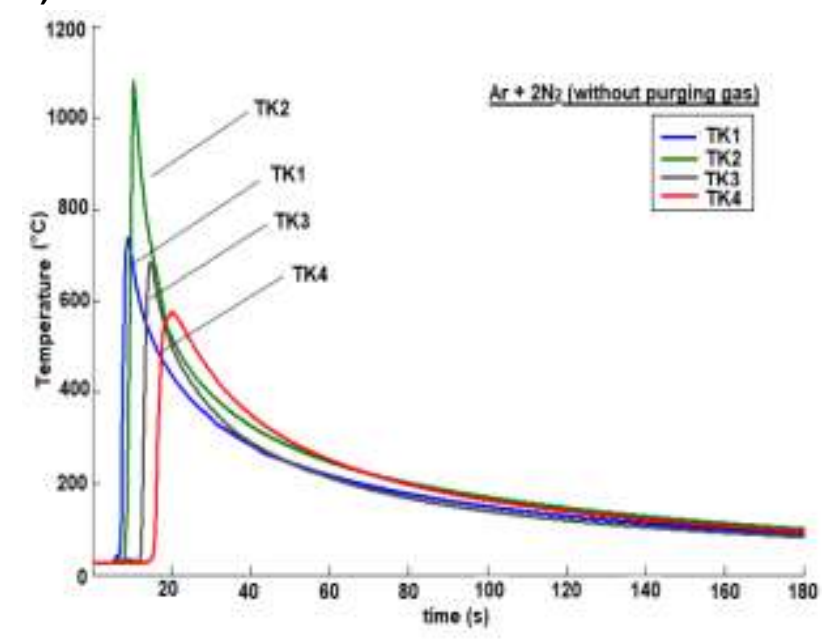

b)

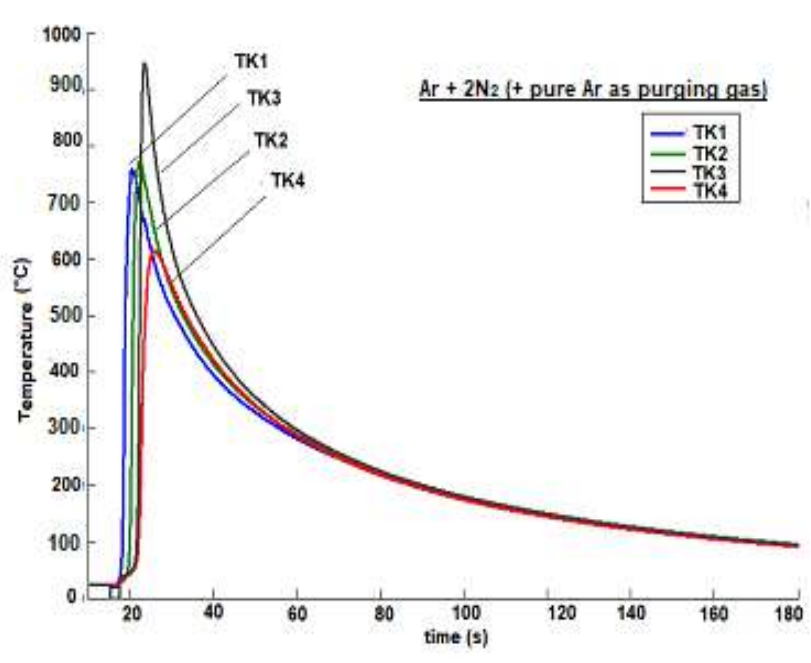

Figure 3: Distribution of temperatures for samples (a) \#1N - Ar $+2 \% \mathrm{~N}_{2}$ as shielding gas without any purging gas and (b) \#2NP - $\mathrm{Ar}+2 \% \mathrm{~N}_{2}$ with pure argon as purging gas.

\subsection{Cooling rates}

Table 4 presents the peak temperature which are within the phase transformation and austenite reformation 
ranges $\left(1300^{\circ} \mathrm{C}\right.$ to $\left.800^{\circ} \mathrm{C}\right)[12,13]$. The mean of the cooling rate for the temperature range $800^{\circ} \mathrm{C}$ to $500^{\circ} \mathrm{C}$ and $500^{\circ} \mathrm{C}$ to $300^{\circ} \mathrm{C}$ is calculated in ${ }^{\circ} \mathrm{C} . \mathrm{s}^{-1}$. The values reported in 5 and 6 Tables are the arithmetic means among the thermocouple readings, as long as the peak temperature is $800^{\circ} \mathrm{C}$ and $500^{\circ} \mathrm{C}$, respectively. For sample welded without purging gas, higher temperature peak and high cooling rates for 800 to $500^{\circ} \mathrm{C}$ range were observed (see Tables 4 and 5).

Table 4: Peak temperature for each distance from the joint line.

\begin{tabular}{ccc}
\hline $\begin{array}{c}\text { Distance } \\
(\mathbf{m m})\end{array}$ & \multicolumn{2}{c}{ Peak temperature, ${ }^{\circ} \mathbf{C}$} \\
\cline { 2 - 3 } & $\mathbf{A r + 2 \% N _ { 2 }}$ & $\begin{array}{c}\mathbf{A r}+\mathbf{2} \% \mathbf{N}_{\mathbf{2}} \\
\mathbf{+} \text { Purging Gas }\end{array}$ \\
\hline 1 & $1080 \pm 54$ & $947.9 \pm 48$ \\
\hline 1.5 & $736 \pm 29$ & $773.7 \pm 38$ \\
\hline 1.8 & $685.1 \pm 27$ & $759.2 \pm 31$ \\
\hline 3 & $572.7 \pm 29$ & $614.2 \pm 24$ \\
\hline
\end{tabular}

Table 5: Cooling rates for $800^{\circ} \mathrm{C}$ and $500^{\circ} \mathrm{C}$ temperature range for each distance from the joint line.

\begin{tabular}{ccc}
\hline \multirow{2}{*}{$\begin{array}{c}\text { Distance } \\
(\mathbf{m m})\end{array}$} & \multicolumn{2}{c}{ Mean cooling rate for $\Delta \mathrm{t}_{\mathbf{8 - 5}}\left({ }^{\circ} \mathbf{C . s}^{-1}\right)$} \\
\cline { 2 - 3 } & $\mathbf{A r + 2} \% \mathrm{~N}_{\mathbf{2}}$ & $\begin{array}{c}\mathbf{A r + 2} \% \mathbf{N}_{\mathbf{2}} \\
+ \text { Purging gas }\end{array}$ \\
\hline 1 & $41.1 \pm 1.6$ & $27.3 \pm 1.2$ \\
\hline 1.5 & $26.3 \pm 1.1$ & $24.1 \pm 0.9$ \\
\hline 1.8 & - & $22.3 \pm 1.1$ \\
\hline 3 & - & - \\
\hline
\end{tabular}

As seen in Table 6, the cooling rates for intervals for $500^{\circ} \mathrm{C}$ and $300^{\circ} \mathrm{C}$ did not show great variation when purging gas was used. In this temperature range, the great convergence of the curves is observed using purging gas (see Fig. 3 (b)). So, it is possible to suggest that the beneficial effect of the purging gas is linked with the stabilization of the temperature distribution.

Table 6: Cooling rates for $500^{\circ} \mathrm{C}$ and $300^{\circ} \mathrm{C}$ temperature range for each distance from the joint line.

\begin{tabular}{ccc}
\hline \multirow{2}{*}{$\begin{array}{c}\text { Distance } \\
(\mathbf{m m})\end{array}$} & \multicolumn{2}{c}{ Mean cooling rate for $\Delta \mathbf{t}_{5-3}\left({ }^{\circ} \mathbf{C}_{\mathbf{s}} \mathbf{s}^{-1}\right)$} \\
\cline { 2 - 3 } & $\mathbf{A r + 2} \% \mathbf{N}_{\mathbf{2}}$ & $\begin{array}{c}\text { Ar+2\% } \\
+ \text { Purging gas }\end{array}$ \\
\hline 1 & $8,1 \pm 0.6$ & $8.4 \pm 0.4$ \\
\hline 1.5 & $9.6 \pm 0.5$ & $8.2 \pm 0.4$ \\
\hline 1.8 & $10.9 \pm 0.7$ & $7.9 \pm 0.3$ \\
\hline 3 & $8.9 \pm 0.6$ & $8.3 \pm 0.4$ \\
\hline
\end{tabular}

Table 7: Holding time above $500^{\circ} \mathrm{C}$ for each distance from the joint line.

\begin{tabular}{|c|c|c|}
\hline \multirow[b]{2}{*}{$\begin{array}{c}\text { Distance } \\
(\mathrm{mm})\end{array}$} & \multicolumn{2}{|c|}{ Holding time at $500^{\circ} \mathrm{C}(\mathrm{s})$} \\
\hline & $\mathrm{Ar}+2 \% \mathrm{~N}_{2}$ & $\begin{array}{c}\text { Ar+2\% } \mathrm{N}_{2} \\
+ \text { Purging gas }\end{array}$ \\
\hline 1 & $11.8 \pm 0.6$ & $13.1 \pm 0.7$ \\
\hline 1.5 & $8.1 \pm 0.4$ & $11.3 \pm 0.5$ \\
\hline 2 & $6.3 \pm 0.3$ & $11.6 \pm 0.6$ \\
\hline 3 & $8.1 \pm 0.4$ & $9.7 \pm 0.4$ \\
\hline
\end{tabular}

With regards to holding time at $500^{\circ} \mathrm{C}$ (Table 7), it can be observed that the purging gas promoted a longer holding time above $500{ }^{\circ} \mathrm{C}$ in the HAZ. This results shows that the adequate protective gas condition can improve the nitrogen diffusion in order to promote austenite reformation $[6,14]$.

\section{Conclusion}

Based on the experimental results from type UNS S32304, following conclusions are made:

The cooling rates were obtained and the effect of purging gas on temperature distribution in HAZ was observed for both plates. The joints welded without any purging gas revealed high peak temperature and cooling rates for $\Delta t_{8-5}$ range. It's was observed a larger weld joint with coarse surface. For joint welded with pure $\mathrm{Ar}$ as purging gas, convergent cooling rates at low temperature and smaller width of the weld bead were observed. Furthermore, high values of the holding time above $500^{\circ} \mathrm{C}$ for this sample were found. It is suggested for future works to investigate the nitrogen diffusion in HAZ in duplex stainless steel UNS S32304 welds.

\section{Acknowledgement}

The authors would like to express their gratitude to the colleagues of the Federal University of Espírito Santo (UFES) responsible of the Welding Laboratory (LabSolda) for the cooperation during welding preparation. Special thanks to CAPES and CNPq for financial supports.

\section{References}

[1] HOSSEINI, V. A.; et al. Nitrogen loss and effects on microstructure in multipass TIG welding of a super duplex stainless steel. Materials \& Design, 98, p. 88-97, 2016.

[2] POORHAYDARI, K.; et al. Estimation of cooling rate in the welding of plates with intermediate thickness. Welding Journal 84.10 p.149s-155s, 2005.

[3] KUMAR, A.; et al. Optimization of pulsed TIG welding process parameters on mechanical properties of AA 5456 Aluminum alloy weldments. Materials \& Design, 30.4, p.1288-1297, 2009.

[4] TABAN, E.; et al. Effect of the purging gas on properties of $304 \mathrm{H}$ GTA welds. Welding Journal 93.4, p. 124s-130s, 2014.

[5] SALES, A. M; et al. Effect of nitrogen in shielding gas of keyhole GTAW on properties of duplex and superduplex welds. Welding in the World, p.1-8, 2017.

[6] CHEN, L,; et al. Influence of cooling rate on microstructure evolution and pitting corrosion resistance in the simulated heat-affected zone of 2304 duplex stainless steels. Corrosion Science. 58 p.168-174, 2012.

[7] TAN, H,; et al. Influence of welding thermal cycles on microstructure and pitting corrosion resistance of 
2304 duplex stainless steels. Corrosion Science,55 p. 368-377, 2012.

[8] Henrik, S.; et. al. Austenite reformation in the heataffected zone of duplex stainless steel 2205. Materials Science and Engineering: A, 418.1 250-256, 2006.

[9] BETINI, E. G.; et al. Experimental Study of the Temperature Distribution in Welded Thin Plates of Duplex Stainless Steel for Automotive Exhaust Systems SAE Technical Paper. 2016-01-0503, 2016.

[10] TSENG, K. H.; et al. The effect of pulsed GTA welding on the residual stress of a stainless steel weldment. Journal of Materials Processing Technology 123.3, p.346-353, 2002.

[11] TABAN, E; et al. Effect of the Purging Gas on Properties of Ti Stabilized AISI 321 Stainless Steel TIG Welds. Materials Testing. 56.11-12 p. 950-957, 2014.
[12] Muthupandi, et al. Effect of nitrogen addition on formation of secondary austenite in duplex stainless steel weld metals and resultant properties. Science and Technology of Welding and Joining, 9(1) p.47-52, 2004.

[13] Lin, Y. C. and Chen, P. Y. Effect of nitrogen content and retained ferrite on the residual stress in austenitic stainless steel weldments. Materials Science and Engineering: A, 307(1) 165-171, 2001.

[14] HERTZMAN, S.; et al. An experimental and theoretical study of heat-affected zone austenite reformation in three duplex stainless steels. Metallurgical and materials transactions A. 28.2.p. 277285, 1997. 